\title{
Phytochemical Analysis and Effect of Various Parameters on the Extraction Yield of Flavonoids from the Citrus medica L Peel Extract
}

\author{
M.Parvathi Nandan ${ }^{1}$, Dr. Meena Vangalapati ${ }^{2}$ \\ M.Tech, Centre for Biotechnology, Dept of Chemical Engg., AUCE (A), Andhra University, A.P, India ${ }^{1}$ \\ Associate Professor, Centre for Biotechnology, Dept of Chemical Engg., AUCE (A), Andhra University, A.P, India ${ }^{2}$
}

\begin{abstract}
Citrus medica L, widely known as Citron belongs to family Rutaceae. Its fruit peel is considered as an important source of dietary phenolics and flavonoids. The objective of this work is to perform the Qualitative phytochemical analysis for identifying the various compounds present in the peel extract and to study the effect of various parameters on the extraction yield of flavonoids (quercetin, rutin, and kaempferol). For the extraction of flavonoids, the optimum results were observed for the effect of different organic solvents such as: methanol, ethanol, ethylacetate and water, with various concentrations $(20 \%-100 \%, \mathrm{v} / \mathrm{v})$, temperatures $\left(40^{\circ} \mathrm{C}-60^{\circ} \mathrm{C}\right)$, extraction times $(1-5$ hrs), extraction $\mathrm{pH}(2-6)$ and material ratio (1:10-1:50). Results showed that maximum amount of quercetin, rutin and kaempferol of concentrations $21.4 \mu \mathrm{g} / \mathrm{ml}, 46.8 \mu \mathrm{g} / \mathrm{ml}$ and $12.3 \mu \mathrm{g} / \mathrm{mlwere}$ obtained at optimum conditions of $80 \%$ methanol at $\mathrm{pH}-5$ of $50^{\circ} \mathrm{Ctemperature}$ and $1: 30 \%$ of material ratio for $4 \mathrm{hrs}$ extraction time.
\end{abstract}

Keywords: Flavonoids (Quercetin, Rutin, and Kaempferol), Citrus medica L (Citron fruit), Methanol.

\section{INTRODUCTION}

Polyphenols constitute one of the most common and and Western Ghats of India [10]. It is more commonly widespread groups of substances in flowering plants, occurring present in the Mediterranean region [11], central and in all vegetative organs, as well as in flowers and fruits. These southern parts of America. In ancient times, the citron was molecules are involved in many physiological processes such used mainly for medical purposes: to combat sea sickness, as cell growth, root formation, seed germination and fruit pulmonary troubles, intestinal ailments, and other ripening. Moreover, these compounds are considered as disorders. The peel of Citrus fruits is a rich source of secondary metabolites involved in the chemical defense of flavanones and many polymethoxylated flavones which plants against predators, pathogens, environmental stresses and are very rare in other plants. Quercetin and hesperidin in plant-plant interferences. Phenolic compounds represent a have many biological activities such as antioxidant, unique and a functional place, composed of bioactive products, antimutagenic effect, analgesic, anti-inflammatory etc, present in plant-derived foods and beverages and included in [12].

the formulations of well-marketed cosmetic and pharmaceutical products. Furthermore, polyphenols exhibit However, to the best of our knowledge, optimizing the various biological activities such as anticancer, antioxidant, extraction of phenolic compounds from Citrus medica L antimicrobial and anti- inflammatory activities. Therefore, in peel extract using different extraction conditions has not recent years, thedetermination of phenolic compounds been reportedyet. Hence, the purpose of the current study concentrations in fruits, vegetables[2] and some aromatic was to investigate the effects of different extracting and medicinal plants has been of increasing interest in the conditions (organicsolvent type, concentration of organic scientific community. In order to recover bioactive solvent, temperature, $\mathrm{pH}$, material ratio and time) on the compounds from plant raw materials, extraction is widely extraction of phenolic compounds; flavonoids (quercetin, used and it constitutes the first important step [3]. rutin, and kaempferol) from Citrus medica L peel extract. Different solvents and techniques are used for the extraction of polyphenols from there are several experimental factors that can influence the rate of extraction and the quality of extracted bioactive phenolic compounds. These factors include extraction method, Solvent type used and solvent concentration [4], temperature, $\mathrm{pH}$ of extraction [5], extraction time [6], and solvent-to-sample ratio [7].Different plants may require different extraction conditions to achieve the optimum recovery of phenolic compounds [8], [9]. The family Rutaceae includes aromatic and medicinal plants, which are used in traditional medicine. Citrus medica $\mathrm{L}$ is commonly known as citron, grown in Assam, central India 


\subsection{Qualitative analysis}

Preliminary phytochemical Analysis of the crude peel powder of the fruit collected was determined as follows:

Test for reducing sugars : (200 mg plant material in 10 $\mathrm{ml}$ distilled water, filtered); a $2 \mathrm{ml}$ of filtrate $+2 \mathrm{ml}$ of Fehling's solution and boiled for $10 \mathrm{~min}$, thick brick red precipitate indicated the presence of reducing sugars.

Test for aminoacids: (200 mg plant material in $10 \mathrm{ml}$ distilled water, filtered); a $2 \mathrm{ml}$ of filtrate +3 drops of $5 \%$ $\mathrm{v} / \mathrm{v}$ of Ninhydrin reagent and boiled, blue coloration indicate the presences of amino acids.

Test for proteins: A $2 \mathrm{ml}$ of filtrate $+1 \mathrm{ml}$ of $4 \% \mathrm{w} / \mathrm{v}$ $\mathrm{NaOH}$ and few drops of $1 \% \mathrm{w} / \mathrm{v}$ copper sulphate solution were added and a blue color was observed indicate the presence of proteins.

Test for Steroids: A $2 \mathrm{ml}$ filtrate $+1 \mathrm{ml}$ of chloroform. Then 3-4 drops of acetic anhydride and 3 drops of concentrated sulphuric acid added by sides of the test tube. The upper layer turns red and sulphuric acid layer showed yellow with green fluorescence indicate the presence of steroids.

Test for Flavonoids: $(200 \mathrm{mg}$ plant material in $10 \mathrm{ml}$ ethanol, filtered); A $2 \mathrm{ml}$ filtrate + conc. $\mathrm{HCl}+$ magnesium ribbon pink tomato red color indicated the presence of flavonoid.

Test for terpenoids (Liebermann- Burchard reaction): (200 mg plant material in $10 \mathrm{ml}$ chloroform, filtered); A $2 \mathrm{ml}$ filtrate $+2 \mathrm{ml}$ acetic anhydride + conc. $\mathrm{H}_{2} \mathrm{SO}_{4}$. Bluegreen ring indicated the presence of terpenoids.

Test for Cardiac glycosides (Keller-Kiliani test): A $2 \mathrm{ml}$ filtrate $+1 \mathrm{ml}$ glacial acetic acid $+\mathrm{FeCl} 3+$ conc. $\mathrm{H} 2 \mathrm{SO} 4)$; green blue color indicated the presence of cardiac glycosides.

Test for Fattyacids: A $0.5 \mathrm{ml}$ of filtrate $+5 \mathrm{ml}$ of ether, allow it for evaporation on filter paper and dried the filter paper, appearance of transparence on filter paper indicated the presence of fatty acids.

Test for Alkaloids: (200 $\mathrm{mg}$ plant material in $10 \mathrm{ml}$ methanol, filtered); A $2 \mathrm{ml}$ filtrate $+1 \% \mathrm{HCl}+$ steam, 1 $\mathrm{ml}$ filtrate +6 drops of Dragendroff reagent, orange precipitate indicated the presence of respective alkaloids

Test for Tannins: (200 mg plant material in $10 \mathrm{ml}$ distilled water, filtered); $\mathrm{A} 2 \mathrm{ml}$ filtrate $+2 \mathrm{ml} \mathrm{FeCl} 3$, blueblack precipitate indicated the presence of Tannins.

Test for Saponins (frothing test): A $0.5 \mathrm{ml}$ filtrate $+5 \mathrm{ml}$ distilled water); frothing persistence indicated presence of saponins.

Test for Phenols: A $2 \mathrm{ml}$ filtrate $+1 \mathrm{ml}$ of alcohol and then few drops of neutral ferric chloride solution was added, blue colour formation indicated the presence of phenols.

\subsection{Extract preparation:}

Two grams of peel powder Citrus medica peel were extracted using $50 \mathrm{ml}$ of extraction solvent with different concentrations, introduced in conical flask of capacity $100 \mathrm{ml}$ sealed with parafilm and wrapped with aluminum foil to prevent solvent loss and exposure to light and the mixture was stirred at $150 \mathrm{rpm}$ for a particular duration. After completing the extraction process, the extract was filtered using Whatman No. 1 filter paper in order to obtain a clear crude extract solution.To determine the optimal conditions for phenolic and flavonoids extraction from Citrus medica $L$ peel, the extraction conditions were set according to the experimental design described below:

- Organic solvents type: Three kinds of organic solvents (methanol, ethanol and acetone) were selected. Distilled water was tested as control.

- Solvent concentrations: Five different concentrations $(20 \%, 40 \%, 60 \%, 80 \%$ and $100 \%$ v/v) of solvent were prepared in distilled water.

- Extraction time: Five different time intervals (1, 2, 3, 4 and 5 hours) for the extraction were chosen.

- Extraction temperatures: Four different temperatures $\left(30^{\circ} \mathrm{C}, 40^{\circ} \mathrm{C}, 50^{\circ} \mathrm{C}\right.$ and $\left.60^{\circ} \mathrm{C}\right)$ were used to find the optimum temperature for the extraction of flavonoids and phenolics

- Extraction pH: Five different pH (2, 3, 4, 5 and 6) were selected to find the optimum $\mathrm{pH}$ for extraction.

- Material ratio (w/v): Different amounts of sample (Peel powder of Citrusmedica L to solvent ratio) viz. 1:10, $1: 20,1: 30,1: 40$ and 1:50 were used to find out the maximum concentrations of quercetin, rutin and kaempferol.

\subsection{Estimation of Quercetin:}

Aluminum chloride method was used for quercetin determination[14]. In this method Quercetin was determined by using a standard graph For this purpose, the calibration curve of quercetin was prepared by taking $1 \mathrm{ml}$ of standard or extract solution of different concentrations $(2,4,6,8,10 \mu \mathrm{g} / \mathrm{ml})$ into $10 \mathrm{ml}$ test tubes, containing $4 \mathrm{ml}$ of distilled water. $0.3 \mathrm{ml}$ of $5 \% \mathrm{NaNO}_{2}$ was added to the test tube. After $5 \mathrm{~min}, 0.3 \mathrm{ml} 10 \% \mathrm{AlCl}_{3}$ was added to the mixture. At the 6th min add $2 \mathrm{ml}$ of $1 \mathrm{M} \mathrm{NaOH}$ was added and volume made up to $10 \mathrm{ml}$ with distilled water. The absorbance was noted at 510nm using UV-Visible spectrophotometer.

\subsection{Estimation of rutin:}

Rutin concentration was determined by preparing a standard graph from working stock solution of rutin which is prepared by dissolving $50 \mathrm{mg}$ of rutin in $50 \mathrm{ml}$ of methanol $(1000 \mu \mathrm{g} / \mathrm{ml})$ [15]. A quantity of Citrus medica powder $50 \mathrm{mg}$ was transferred to $50 \mathrm{~mL}$ volumetric flask and dissolved in methanol and final volume was made up with methanol.

The sample solution was then filtered through Whatman filter paper No.1. From the above solution $0.373 \mathrm{ml}$ of solution was taken and diluted to $10 \mathrm{~mL}$ with methanol to get final concentration. The concentration of rutin was determined by taking absorbance value at $359 \mathrm{~nm}$ using UV-Visible spectrophotometer.

\subsection{Estimation of kaempferol:}

Kaempferol concentration was determined by preparing a standard graph from working stock solution of kaempferol which is prepared by dissolving $5 \mathrm{mg}$ of kaempferol in $5 \mathrm{ml}$ of methanol $(1000 \mu \mathrm{g} / \mathrm{ml})$ [16]. The working stock solution of kaempferol $(10 \mu \mathrm{g} / \mathrm{ml})$ was prepared by diluting the stock solution. 
A quantity of Citrus medica extract50mg was transferred The choice of extraction solvents is important for to $50 \mathrm{~mL}$ volumetric flask and dissolved in methanol and maximum extraction of phytoconstituents. Different final volume was made up with methanol. The sample organic solvents such as methanol, ethanol, ethylacetate solution was then filtered through Whatman filter paper and water were used to extract the optimum yield. No.1. From the above solution $0.1 \mathrm{ml}$ of solution was taken Methanol gave maximum yield of Quercetin, Rutin, and and diluted to $10 \mathrm{~mL}$ with methanol to get final Kaempferol of concentrations $8.3 \mu \mathrm{g} / \mathrm{ml}, 20.61 \mu \mathrm{g} / \mathrm{ml}$, and concentration. The concentration of rutin was determined $5.7 \mu \mathrm{g} / \mathrm{ml}$ from Citrus medica peel powder. The results were by taking absorbance value at $265 \mathrm{~nm}$ using UV-Visible shown in the Figure 1.

spectrophotometer.

\section{RESULTS AND DISCUSSION}

\subsection{Qualitative analysis}

Preliminary phytochemical analysis revealed the presence of primary metabolites like carbohydrates, proteins and fattyacids, and secondary metabolites like steroids, alkaloids,phenols, tannins and flavonoids etc. were present in trace amounts in the peels.At the same time, the phytochemical constituents like Cardiac glycosides, saponins and terpenoids are absent, and the results were shown in the table 1:

\begin{tabular}{|l|c|l|}
\hline Phytochemical tests & $\begin{array}{c}\text { Peel } \\
\text { extract }\end{array}$ & \multicolumn{1}{|c|}{ Inference } \\
\hline Fehling's test & + & ydratespresent \\
\hline Ninhydrin test & + & Aminoacids present \\
\hline Biuret test & + & Proteins present \\
\hline Test for steroids & + & Steroids present \\
\hline Keller-Kiliani test & - & glycosides absent \\
\hline Test for alkaloids & + & Alkaloids present \\
\hline Test for saponins & - & Saponins absent \\
\hline Test for phenols & + & Phenols present \\
\hline Test for fatty acids & + & Fatty acids present \\
\hline Test for flavonoids & + & Flavonoids present \\
\hline Test for terpenoids & - & Terpenoids absent \\
\hline Test for tannins & + & Tannins present \\
\hline
\end{tabular}

Constituents present $=+$, Constituents absent $=$ -

Table 1: Preliminary phytochemical screening of Citrus medica peel extract

3.2 Optimization results for the Extraction of Flavonoids: Effect of Different Solvents on Extraction of Quercetin, Rutin and Kaempferol:

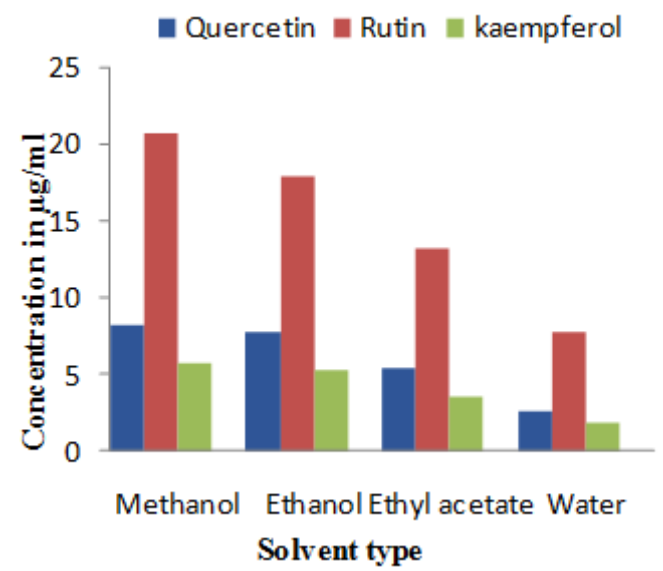

Fig 1: Effect of Different Solvents on Extraction of Quercetin, Rutin and kaempferol
Effect of Different Solvent percentages on Extraction of Quercetin, Rutin and Kaempferol:

Mixtures of methanol with different proportions of water have shown to be more effective in extracting flavonoids. The dried peel powder of Citrus medica was extracted with various percentages of the methanol $(20 \%, 40 \%$, $60 \%, 80 \%$, and $100 \%$ ) were checked for the optimum extraction yield of flavonoids, and the results showed that the maximum rate of Quercetin, Rutin and Kaempferol concentrations of $11.9 \mu \mathrm{g} / \mathrm{ml}, 29.92 \mu \mathrm{g} / \mathrm{ml}$ and $8.24 \mu \mathrm{g} / \mathrm{ml}$ were observed at $80 \%$ of methanol respectively, and the results were shown in Figure 2.

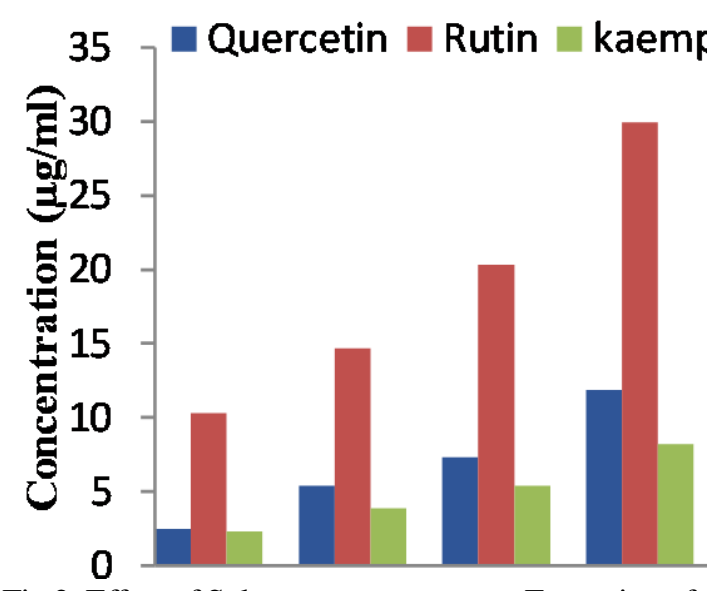

Fig 2: Effect of Solvents percentages on Extraction of Quercetin, Rutin and kaempferol

Effect of Soaking time on extraction of Quercetin, Rutin and Kaempferol:

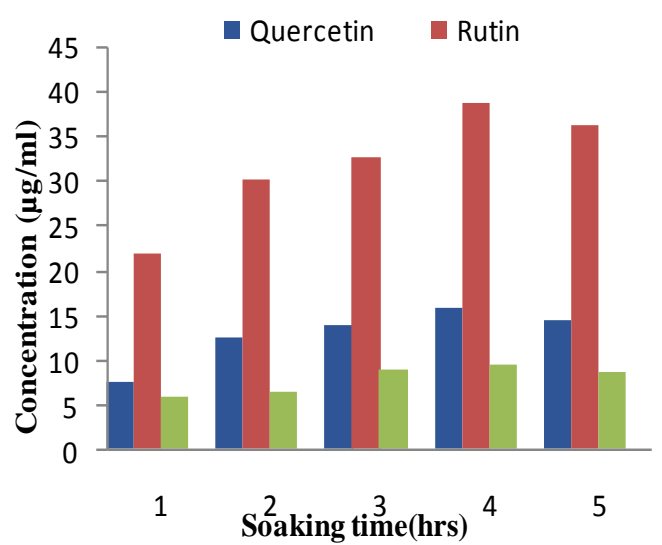

Fig 3: Effect of Soaking time on Extraction of Flavonoids

Soaking time represents another key parameter in optimizing the phenolic compounds extraction. The powder was soaked in 
under proper conditions at different time intervals viz.,1,2, The results showed the maximum concentrations of 3, 4 and 5hrs to investigate the influence on extraction of Quercetin, Rutin, and Kaempferol of $18.72 \mu \mathrm{g} / \mathrm{ml}$, flavonoids. It was observed that, extraction time of $4 \mathrm{hrs} 38.5 \mu \mathrm{g} / \mathrm{ml}$ and $10.8 \mu \mathrm{g} / \mathrm{mlwas}$ obtained at $\mathrm{pH} 5 \mathrm{using}$ was the optimum condition to get maximum concentration methanol as solvent.The results of maximum rate of of Quercetin, Rutin and Kaempferol of concentration extraction of phytoconstituents were shown in the figure.5 $15.82 \mu \mathrm{g} / \mathrm{ml}, 38.7 \mu \mathrm{g} / \mathrm{ml}$ and $9.43 \mu \mathrm{g} / \mathrm{ml}$. The results were shown in figure 3.

Effect of Material ratio on extraction of Quercetin, Rutin and Kaempferol:

Effect of Extraction temperature on extraction of Quercetin, Rutin and Kaempferol:

Different amounts of sample powder to solvent ratio of The effectiveness of extraction process of flavonoids is largely regulated by different experimental parameters particularly by the extraction temperature. An increase of temperature is mainly due to an increase of the diffusion rate and solubility of the extracted substances. Extraction at different temperatures such as $30^{\circ} \mathrm{C}, 40^{\circ} \mathrm{C}, 50^{\circ} \mathrm{C}$ and $60^{\circ} \mathrm{C}$ were used, and the results showed that maximum concentration of Quercetin, Rutin and Kaempferol of $20.1 \mu \mathrm{g} / \mathrm{ml}, 44.2 \mu \mathrm{g} / \mathrm{ml}$ and $11.7 \mathrm{ug} / \mathrm{ml}$ observed at $500 \mathrm{c}$ incubation temperature. The resulte were shown in figure 4.

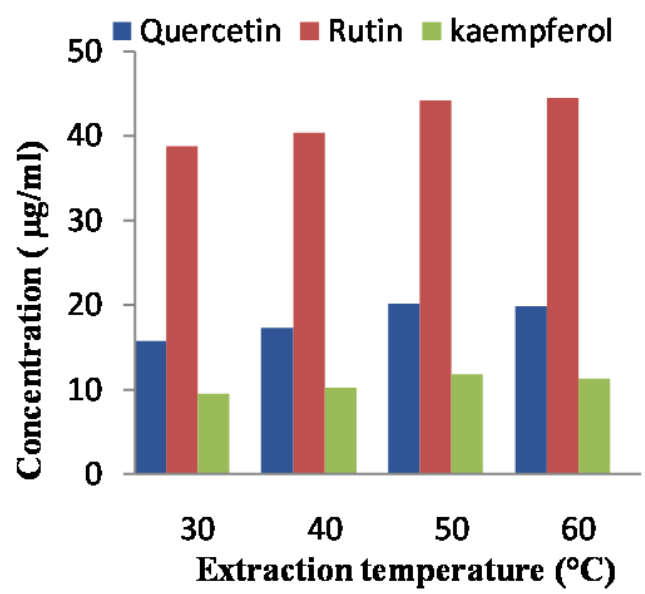

Fig 4: Effect of Extraction temperature on Extraction of Flavonoids

Effect of pH onExtraction of Quercetin, Rutin and Kaempferol:

To determine the effects of various $\mathrm{pH}$ values on extraction yield of flavonoids from the peel of Citrus medicafruit. The extraction yield of components was observed at different $\mathrm{pH}$ values namely $3,4,5,6,7$, and 8 .

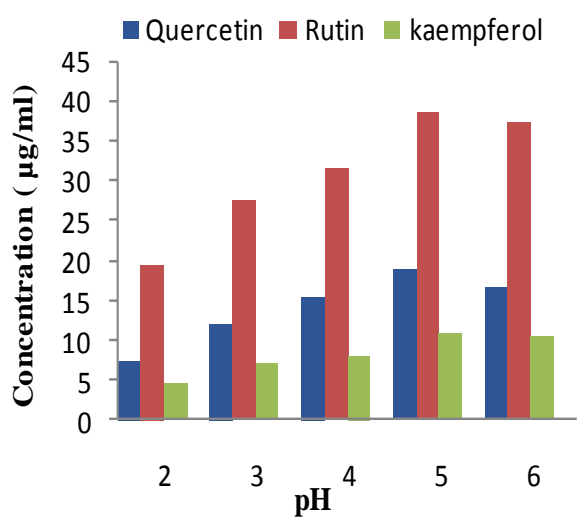

Fig 5: Effect of $\mathrm{pH}$ on Extraction of Flavonoids $1: 10,1: 20,1: 30,1: 40$, and 1:50 were used to find out the maximum concentrations of quercetin, rutin and kaempferol and the results were shown in the figure 6.The results showedthat the higher concentrations of Quercetin, Rutin, and Kaempferol of $21.4 \mu \mathrm{g} / \mathrm{ml}, 46.8 \mu \mathrm{g} / \mathrm{ml}$ and $12.3 \mu \mathrm{g} / \mathrm{mlwas}$ obtained at $1: 30$ materials ratio. Further increase in the material ratio leads to a gradual decrease in the flavonoids content revealing a saturated condition.

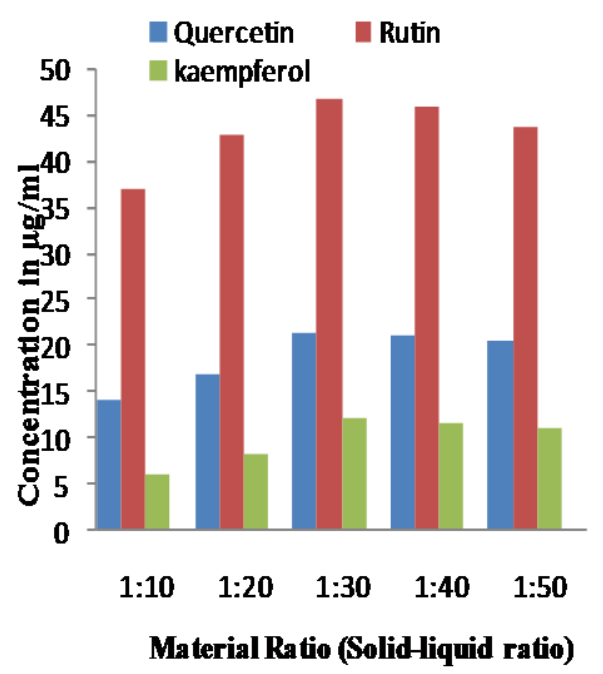

Fig 6: Effect of Material ratio on Extraction of Flavonoids

IV.

CONCLUSION

Experiments were performed for the Qualitative phytochemical analysis and optimization of physicochemical parameters for the extraction of Quercetin, Rutin and Kaempferol from Citrus medica peel powder.The parameters like effects of different solvents, solvent percentages, extraction time, extraction temperature,extraction $\mathrm{pH}$ and material ratio for the extraction of Quercetin, Rutin and Kaempferol and their concentrations were observed from the experimental work. The highest concentration of Quercetin, Rutin and Kaempferol for optimized conditions were $21.4 \mu \mathrm{g} / \mathrm{ml}, 46.8 \mu \mathrm{g} / \mathrm{ml}$ and $12.3 \mu \mathrm{g} / \mathrm{ml}$.

\section{REFERENCES}

[1] Khoddami, A., Wilkes, M.A. and Roberts, T.H. Techniques for Analysis of Plant Phenolic Compounds. Molecules, 2013, 18, 23282375 .

[2] Ignat, I., Volf, I. and Popa, V.I. (2011) A Critical Review of Methods for Characterization of Polyphenolic Compoundsin Fruits and Vegetables. Food Chemistry, 126, 1821-1835.

[3]Santana, C.M., Ferrera, Z.S., Padrón, M.E.T. and Rodríguez, J.J.S. Methodologies for the Extraction of PhenolicCompounds from Environmental Samples: New Approaches. Molecules,2009, 14, 298-320.

[4] Trabelsi, N., Megdiche, W., Ksouri, R., Falleh, H., Oueslati, S., Soumaya, B., Hajlaoui, H. and Abdelly, C. Solvent Effects on Phenolic Contents and 
Biological Activities of the Halophyte Limoniastrum monopetalum Leaves. LWT-Food Science and Technology, 2010, 43, 632-639.

[5] Gironi, F. and Piemonte, V. Temperature and Solvent Effects on Polyphenol Extraction Process from Chestnut Tree Wood. Chemical Engineering Research and Design, 2011, 89, 857-862.

[6] Falleh, H., Ksouri, R., Lucchessi, M.E., Abdelly, C. and Magné, C. Ultrasound-Assisted Extraction: Effect of Extraction Time and Solvent Power on the Levels of Polyphenols and Antioxidant Activity of Mesembryanthemum edule L. Aizoaceae Shoots. Tropical Journal of Pharmaceutical Research,2012, 11, 243-249.

[7] Tan, P.W., Tan, C.P. and Ho, C.W. Antioxidant Properties: Effects of Solid-to-Solvent Ratio on Antioxidant Compounds and Capacities of Pegaga (Centella asiatica). International Food Research Journal, 2011, 18, 557-562.

[8] Jace, D.E. and Shahidul, I. Effects of Extraction Procedures, Genotypes and Screening Methods to Measure theAntioxidant Potential and Phenolic Content of Orange-Fleshed Sweetpotatoes (Ipomoea batatas L.). American Journalof Food Technology, 2012, 7, 50-61.

[9] Chirinos, R., Rogez, H., Campos, D., Pedreschi, R. and Larondelle, Y. Optimisation of Extraction Conditions of Antioxidant Phenolic Compounds from Mashua (Tropaeolum tuberosum Ruíz \& Pavón) Tubers. Journal of Separationand Purification Technology, 2007, 55, 217 225.

[10]Kalpesh Panara Krutika Joshi and K. Nishteswar.A Review on Phytochemical and Pharmacological Properties of Citrus medica Linn.International Journal of Pharmaceutical \& Biological Archives 2012, 3(6):1292-1297.

[11] Beatriz AA, Luis RL. Pharmacological properties of Citrus and their ancient and medieval uses in the Mediterranean region, J Ethnopharmacol 2005, 97, 89.

[12] M. N. I. Bhuiyan, J. Begum, Constituents of Peel and Leaf Essential Oils of Citrus Medica L. Journal of Scientific Research 2009; 1(2):387-92

[13]Kabra AO1, Bairagi GB1, Mahamuni AS2 and Wanare RS1.In vitro Antimicrobial Activity and Phytochemical Analysis of the Peels of Citrus medica L ,International Journal of Research in Pharmaceutical and Biomedical Sciences, 2012, ISSN: 2229-3701,Vol. 3 (1)

[14] Rajeshwari Sahu and Jyoti Saxena, Screening of Total Phenolic and Flavonoid Content in Conventional and Non-Conventional Species of Curcuma, Journal of Pharmacognosy and Phytochemistry, 2013. Vol. 2 No. $1,176-179$.

[15] N P Pawar, V R Salunkhe, Development And Validation Of UV Spectrophotometric Method For Simultaneous Estimation Of Rutin And Gallic Acid In Hydroalcoholic Extract Of Triphala churna, International Journal of PharmTech Research 2013, Vol.5, No.2, pp 724-729.

[16] Darshan R. Telange1, Arun T. Patill, Amol Tatode1, Bhushan Bhoyar, Development and Validation of UV Spectrophotometric Method for the Estimation of Kaempferol in Kaempferol: Hydrogenated Soy Phosphatidylcholine (HSPC) Complex, Pharmaceutical Methods, 2014, Vol 5(1).

\section{BIOGRAPHIES}

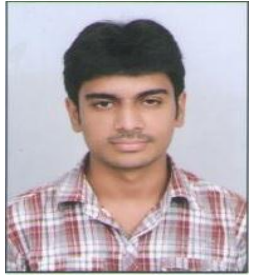

conferences.

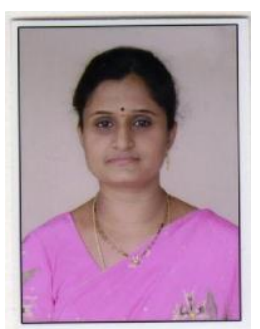

Copyright to IARJSET
National and International Reputed Journals, published 10 monographs/Books.
Mr. M Parvathi Nandan, M.Tech Biotechnology, Department of Chemical Engineering, Andhra University College of Engineering (A), Andhra University, Visakhapatnam, Andhra Pradesh, India. He has attended 5 International

Dr.Meena Vangalapati M.Tech., Ph.D, Associate Professor, Department of Chemical Engineering, Andhra University College of Engineering (A), Andhra University, Visakhapatnam, Andhra Pradesh, India. She has 14 years of teaching experience and published 65 more Papers published in 